\title{
Overcoming sexual sterility in conservation of endangered species: the prominent role of biotechnology in the multiplication of Zelkova sicula (Ulmaceae), a relict tree at the brink of extinction
}

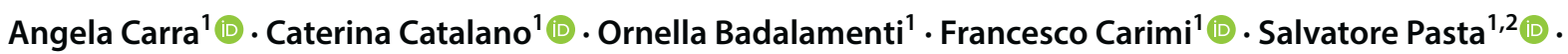

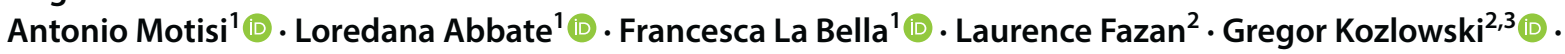 \\ Giuseppe Garfi ${ }^{1}$
}

\begin{abstract}
Biotechnology provides valuable tools to support conservation of plant species, especially in case of threatened taxa or when dealing with seed unavailability, low viability or sterility. However, plant cell culture methods have often to face problems associated with tissue recalcitrance to in vitro systems. Recalcitrance can be related to a variety of triggering factors, involving many efforts and manipulations within one or more of the micropropagation stages before obtaining successful results. An in vitro propagation protocol was developed for Zelkova sicula, a very rare and endangered relict tree, endemic to Sicily (Southern Italy). The species revealed extremely recalcitrant to in vitro culture approaches, but after many trials throughout a number of years an effective micropropagation protocol was completed. The rooting rate was about $84 \%$ of the treated explants, $8 \%$ of which were successfully acclimatized outdoor and reintroduced in the wild within a comprehensive conservation project. The technique allowed to overcome the problems of sexual sterility of this species, hence contributing concretely to contrast the problems connected with its conservation. However, additional efforts need to be carried out in order to refine the acclimatization step and further improve the whole process effectiveness.
\end{abstract}

\section{Key Message}

A micropropagation protocol was developed for the rare and endangered tree species Zelkova sicula. The in vitro procedure allowed to overcome seed sterility providing a plant stock successfully reintroduced in the wild.

Keywords Axillary buds $\cdot$ Clonal species $\cdot$ Ex vitro acclimatization $\cdot$ In vitro propagation $\cdot$ Recalcitrance $\cdot$ Threatened species

Angela Carra

angela.carra@ibbr.cnr.it

1 Institute of Biosciences and BioResources, National Research Council, Corso Calatafimi 414, 90129 Palermo, Italy

2 Department of Biology and Botanic Garden, Unit of Ecology and Evolution, University of Fribourg, Chemin du Musée 10, 1700 Fribourg, Switzerland

3 Natural History Museum Fribourg, Chemin du Musée 6, 1700 Fribourg, Switzerland

\section{Introduction}

Biotechnological techniques are essential in plant preservation programs in order to provide a complementary approach to the traditional in situ and ex situ conservation strategies (Krishnan et al. 2011; Reed et al. 2011). Furthermore, the importance of in vitro culture of plant tissues has notably increased in recent years, especially for the conservation of endemic, rare and threatened species (Hummer 1999; Sarasan et al. 2006; Mallón et al. 2010; Bunn et al. 2011; San José et al. 2017), since it offers many advantages with respect to traditional methods, e.g. (i) no need for repeated collecting of plant material from living trees in the field, (ii) potential production of endless amounts of plantlets from 
very small quantities of parental plant tissue, (iii) theoretically not strict dependence on season cycles, and (iv) relatively rapid production of new plants, that may be difficult to obtain using traditional approaches (Bayraktar et al. 2015). Accordingly, in vitro methods have a major implication when seeds are unavailable, sterile or non-viable and/or when in vivo cuttings have poor rootability (Hummer 1999; Reed et al. 2011).

However, a number of issues mostly relying on the lack of specific knowledge about the optimal conditions for in vitro growth can jeopardize the effectiveness of this method, giving rise to problems of recalcitrance in many taxa. In vitro species recalcitrance is the inability of plants to respond to tissue culture, often with genetic connotation (McCown 2000) or depending on various factors related for instance to plant physiology and/or in vitro culture stresses (Benson 2000). Recalcitrance in shoot formation as well as in root onset may be associated with problems such as endogenous contamination (e.g. by endophytic bacteria or fungi), hyperhydricity or lethal tissue browning (Keskitalo 1999). Hence, the success could be strongly jeopardised, and this could represent a troubling issue especially when dealing with threatened taxa, for which the source material is often very scarce and/or located in remote areas in the wild (Sarasan et al. 2006). In addition, the stabilization stage of a shoot culture system, with uniform and continuous in vitro shootgrowth, is usually most challenging in long-lived perennial woody plants (McCown 2000). As a result, the in vitro culture of such taxa may only be successful after a relatively long period of in vitro 'domestication' (Keskitalo 1999).

The relict tree Zelkova sicula Di Pasquale, Garfì and Quézel (Ulmaceae) is a very rare threatened species, endemic to South-eastern Sicily (Italy). At present it is known to consist of only two single populations restricted to the northern slopes of the Iblei Mountains, province of Siracusa, each including only a few hundred individuals. One population, named ZS1, is located at Bosco Pisano (Municipality of Buccheri); the other one, ZS2, lies in the countryside of Ciranna (Municipality of Melilli) (Garfì et al. 2011, 2017). Since no intra-population genetic variability coupled to strong differences between the two populations has been detected (Christe et al. 2014), it is very likely that each population is clonal, issuing from probably centuries-long sprouting of two single surviving genetic individuals (Garfî and Buord 2012; Gratzfeld et al. 2015). This condition is consistent with the sexual sterility of this tree, probably related to the triploid karyotype (Garfi 1997) and ascertained by unsuccessful natural regeneration and germination tests (authors' personal observations).

According to a number of criteria, Z. sicula is ranked in the IUCN (International Union for Conservation of Nature) Red List as Critically Endangered (Garfì et al. 2017). The main threatening factors, besides the ineffective sexual reproduction, include environmental constraints (e.g. summer water stress) and direct and indirect human disturbances, such as wildfires and climate change. The latter is among the most critical ones since in the recent decades the current refugial area reveal to be more and more unsuitable to the persistence of the species, whose diffusion in new locations hence appears as the last chance to secure its future survival in the wild (Alkemade et al. 2009; Brooker et al. 2011).

Based on these topics, in vitro propagation techniques become of crucial importance for the conservation of such a troubled species. In order to design an effective protocol, we have carried out many trials in the last years, differing by the collecting period of plant material throughout the year, the culture medium, the type and concentration of growth regulators, the type of plant tissues (woody or green apical explants, origin from branch shoots or root suckers, leaf explants, flower buds). Such a huge effort impacted against the extreme recalcitrance of $Z$. sicula and on the whole at least 24 diverse treatments ( 3 for sterilization, 14 for regeneration and 7 for rooting, including not less than 4 repeated cycles each) had to be tested before successfully completing the entire propagation system, from in vitro introduction to acclimatization outdoor.

In the present paper, we illustrate the results of the most effective protocol that, though still needing to be refined in the final acclimatization step, nevertheless allowed obtaining for the first time some new plantlets of Z. sicula to use within in situ and ex situ conservation programs.

\section{Materials and methods}

\section{Plant material and axenic culture establishment}

Woody explants of $Z$. sicula, 10-15 cm long, were harvested from both known populations ZS1 and ZS2. The collection was carried out on December 2014 since according to a number of preliminary trials winter season revealed as the best period with regard to the low rate of explant contamination. In the laboratory, explants were cut into nodal segments about 3.0-3.5 cm in length, rinsed two times in distilled water added with two drops of Tween 20 for $5 \mathrm{~min}$, and finally dipped three times in sterile distilled water for $5 \mathrm{~min}$.

After many adjusting trials that allowed overcoming the problems of endophytic fungi and/or bacterial contamination the following sterilization procedure was elaborated. Shoot segments were disinfected under laminar flow with ethanol $70 \%$ for $5 \mathrm{~min}$, and then rinsed once with sterile distilled water for $5 \mathrm{~min}$. Next, explants were soaked in a $0.05 \%$ solution of $\mathrm{HgCl}_{2}$ for $10 \mathrm{~min}$, followed by three rinses with sterile distilled water for 5 min each. After sterilization, explants were dipped in $2 \%$ plant preservative mixture 
(PPM) over night and kept at room temperature under constant magnetic shaking.

Based on the percentage of contaminations, that differed according to the population of origin, for the next experimental steps we decided to use only plant material coming from ZS2 which showed a significantly lower microbial contamination rate compared with $\mathrm{ZS} 1$.

\section{Media and culture conditions}

For axenic culture establishment, shoot multiplication, plant development and rooting we used Petri dishes $10 \mathrm{~cm}$ in diameter by $2.5 \mathrm{~cm}$ in height and $25 \mathrm{ml}$ capacity, sealed with Parafilm MTM.

Explants were incubated in Woody Plant Medium (WPM, Lloyd and McCown 1980) solidified substrate (7 g/L Plantagar S1000, B\&V, Italy), with $30 \mathrm{~g} / \mathrm{L}$ sucrose as carbon source. The $\mathrm{pH}$ of the media was adjusted to $5.7 \pm 0.1$ with $0.5 \mathrm{M} \mathrm{KOH}$ before autoclaving at $121{ }^{\circ} \mathrm{C}$ and $1 \mathrm{~atm}$ for $20 \mathrm{~min}$.

PPM was supplemented to the medium at various percentages, according to the different steps: $0.2 \%$ in the in vitro introduction step, $0.1 \%$ in the multiplication step and for some rooting treatments.

For the in vitro introduction step, woody explants were cultivated on WPM medium without growth regulators. For the multiplication the following plant growth regulators (PGR), filter-sterilized through a $0.22 \mu \mathrm{m}$ nylon filter after autoclaving, were added to the medium: 6-benzylaminopurine (BAP, Sigma B-4308), zeatin (ZEA, Sigma Z0163), $N$-(2-chloro-4-pyridyl)- $N$ '-phenylurea (4-CPPU, Sigma C-2791) and thidiazuron (TDZ, Sigma P-6186), whereas for rooting we used indol-3-butyric acid (IBA, Sigma I-5386) and 3-indoleacetic acid (IAA, Sigma I-2886).

Explants were maintained in a climate chamber at $25 \pm 1{ }^{\circ} \mathrm{C}$ under a $16 \mathrm{~h}$ day length, and a photosynthetic photon flux of $50 \mu \mathrm{mol} \mathrm{m}{ }^{-2} \mathrm{~s}^{1}$ provided by Osram cool-white $18 \mathrm{~W}$ fluorescent lamps.

\section{Shoot multiplication}

After about 4 weeks from culture establishment, two-node stem segments, approximately $2 \mathrm{~cm}$ in length, were excised from initial woody explants and subcultured for multiplication under different combinations of cytokinins of two different classes: the N6-substituted adenine derivative BAP and ZEA, and the two synthetic phenylurea derivatives 4-CPPU and TDZ. Four hormonal combinations were compared (Table 1): $2.2 \mu \mathrm{M}$ BAP (treatment A), $8.0 \mu \mathrm{M}$ 4-CPPU + 2.3 $\mu \mathrm{M}$ TDZ (treatment B), $1.2 \mu \mathrm{M}$ ZEA (treatment $\mathrm{C}$ ) and $2.3 \mu \mathrm{M}$ ZEA (treatment D).

Explants were subcultured at 30-days intervals and the effect of each treatment was checked 90 days after culture
Table 1 Treatments used for shoot multiplication

\begin{tabular}{ll}
\hline Treatment & PGRs (type and concentration) \\
\hline A & $2.2 \mu \mathrm{M}$ BAP \\
B & $8 \mu \mathrm{M} 4-\mathrm{CPPU}+2.3 \mu \mathrm{M} \mathrm{TDZ}$ \\
$\mathrm{C}$ & $1.2 \mu \mathrm{M}$ ZEA \\
$\mathrm{D}$ & $2.3 \mu \mathrm{M}$ ZEA \\
\hline
\end{tabular}

Table 2 Treatments used for preliminary rooting tests, based on binodal shoots issued from the multiplication treatment $\mathrm{D}(2.3 \mu \mathrm{M}$ ZEA)

\begin{tabular}{ll}
\hline Treatment & $\begin{array}{l}\text { PGRs (type and concen- } \\
\text { tration) and other culture } \\
\text { conditions }\end{array}$ \\
\hline $\mathrm{E}$ & IAA $5 \mu \mathrm{M}(\mathrm{L})$ \\
$\mathrm{F}$ & IAA $10 \mu \mathrm{M}(\mathrm{L})$ \\
$\mathrm{G}$ & IBA $5 \mu \mathrm{M}(\mathrm{L})$ \\
$\mathrm{H}$ & IBA $10 \mu \mathrm{M}(\mathrm{L})$ \\
$\mathrm{I}$ & IBA $5 \mu \mathrm{M}(\mathrm{D}-\mathrm{L})$ \\
$\mathrm{J}$ & IBA $10 \mu \mathrm{M}(\mathrm{D}-\mathrm{L})$ \\
\hline
\end{tabular}

(L) Shoots directly incubated on medium in the light, (D-L) Shoots incubated on medium with IBA in the dark for 6 days and then transferred to GRF medium in the light

initiation by recording the percentage of responsive explants, the number of new shoots per explant, and the average length of newly regenerated shoots.

\section{Plant rooting}

Actively growing bi-nodal shoots, obtained from the most performing treatment of the multiplication step (treatment D, ZEA $2.3 \mu \mathrm{M}$ ), were used for rooting. Individual shoots were cut 4 weeks after culture initiation and cultured under different rooting treatments.

Initially, during preliminary tests (see Table 2), explants were plated on WPM medium supplemented with two different rooting PGRs, IAA and IBA at either $5 \mu \mathrm{M}$ or $10 \mu \mathrm{M}$, in light conditions (treatments E, F, G, H). Moreover, to test the light effect and the influence of continuous presence of IBA, an additional group of shoots was cultured with IBA at 5 or $10 \mu \mathrm{M}$ for 6 days in the dark and then transferred to growth regulator free (GRF) medium in the light (treatments I, J).

Results addressed the following experiments on discarding IBA and using only IAA (treatments E and F), which provided the best performance in term of global quality of rooting. According to that, six different treatments on root formation were newly tested (Table 3). Explants were plated on WPM supplemented with IAA at 5 or $10 \mu \mathrm{M}$, with and without addition of $0.1 \%$ PPM (treatments E, F, E1, F1). Two additional groups of explants were cultured for 7 days 
Table 3 Treatments used for rooting improvement based on treatments $\mathrm{E}$ and $\mathrm{F}$ from the preliminary rooting tests

\begin{tabular}{ll}
\hline Treatment & $\begin{array}{l}\text { PGRs (type and concentration) and other } \\
\text { culture conditions }\end{array}$ \\
\hline E & IAA $5 \mu \mathrm{M}$ \\
$\mathrm{F}$ & IAA $10 \mu \mathrm{M}$ \\
$\mathrm{E} 1$ & IAA $5 \mu \mathrm{M}+0.1 \%$ PPM \\
$\mathrm{F} 1$ & IAA $10 \mu \mathrm{M}+0.1 \%$ PPM \\
E2 & $0.1 \%$ PPM (7 days); IAA $5 \mu \mathrm{M}+0.1 \%$ PPM \\
F2 & $0.1 \%$ PPM (7 days); IAA $10 \mu \mathrm{M}+0.1 \%$ PPM \\
\hline
\end{tabular}

on WPM only supplemented with $0.1 \%$ PPM; next, they were transferred on WPM added with IAA at 5 or $10 \mu \mathrm{M}$ and $0.1 \%$ PPM (treatments E2, F2). Cultures were incubated under the same light conditions described above.

\section{Plant acclimatization}

Plantlets, 3-5 cm tall and with well-developed roots, were moved from the rooting medium to acclimatization, including a preliminary phase under controlled conditions (preacclimatization). The roots were first washed with distilled water to remove agar residues. The plantlets were then transferred into 10-cm diameter crystal-clear polypropylene pots equipped with a "breathing" hermetic cover (vitro-vent pots), containing a 1:1 peat:loam sterilized mixture. The potted plants were placed in a climate chamber at $18 \pm 1{ }^{\circ} \mathrm{C}$ under a $12 \mathrm{~h}$ day length, and a photosynthetic photon flux of $50 \mu \mathrm{mol} \mathrm{m} \mathrm{m}^{-2} \mathrm{~s}^{-1}$ provided by Osram cool-white $18 \mathrm{~W}$ fluorescent lamps.

After 8 weeks under these conditions, the pot cap was replaced by a transparent polyethylene bag, which was gradually perforated. During the next 2 weeks, the plants were ventilated by removing the bags for $1 \mathrm{~h}$ once a week. Plants were watered as needed with diluted (1:10) WPM salts supplemented with 1.2 $\mu \mathrm{M}$ ZEA. The acclimation bags were definitively removed after 4 weeks and the plants were transferred outdoor under natural daylight conditions, but sheltered by a shadowing net for the final acclimatization. The survival rates were recorded after 2 months.

Most of the acclimatized plants were reintroduced in the wild during the autumn seasons 2016 and 2017.

\section{Data analysis}

In vitro experiments were carried out in a completely randomized design and the data were evaluated by analysis of variance. Differences within and between treatments were estimated by average separation analysis, using the least significant difference test (LSD) with the significance level set at $0.05 \%$. Each treatment for shoot multiplication and rooting consisted of 50 uniform explants equally divided into Petri dishes.

The percentage of responsive explants was first considered to evaluate the effects of the different media. For statistical analysis, the following additional parameters were taken into account: length of shoots and number of shoots per explant.

Response to rooting was assessed 1 month after the beginning of the rooting phase, and the following parameters were considered: rooting percentage rate, mean root number per explant and mean root length.

The percentage of successfully acclimatized plants was recorded 2 months after transplanting. Prior to analysis, percentage data were arcsin-square root transformed. Statistical analysis was performed using SigmaStat 3.5 for Windows.

\section{Results}

\section{Shoot multiplication}

During the phase of in vitro culture establishment (Fig. 1A), shoot regeneration generally started within 15 days after culture initiation and the new shoots grew 2.8 to $4.0 \mathrm{~cm}$ in 4 weeks. (Fig. 1B).

Multiple shoot regeneration (Fig. 1C, D) was obtained under all tested treatments, but with variable response according to the hormonal composition (Table 4). The percentage of responsive explants ranged from $13.9 \%$ (treatment B) to $40 \%$ (treatment D), and the latter was significantly different from all the others. The average number of new shoots per responsive explant varied from 1.5 (treatments A, B, C) to 2.1 (treatment D), but with no significant differences among treatments. Finally, the best result in term of mean shoot length $(2.8 \mathrm{~cm})$ was obtained with explants cultured in presence of $2.3 \mu \mathrm{M}$ ZEA (treatment D), and the value was significantly different from all the others (Table 4).

\section{Plant rooting and acclimatization}

On actively healthy growing explants obtained by using ZEA $2.3 \mu \mathrm{M}$, roots began to emerge generally 10 days after culture initiation (Fig. 1E) under all tested combinations, with significant differences among treatments.

Results of the preliminary tests, including the growth regulators IBA or IAA at various concentrations and daylight conditions (Table 2), showed that the percentages of rooted shoots ranged from 5 to $37.1 \%$ (treatments $\mathrm{G}$ and $\mathrm{E}$, respectively) (Table 5). However, in terms of rooting rate there had not been significant differences among treatments, whereas root elongation had been significantly better $(25 \%)$ in explants cultivated in IBA $10 \mu \mathrm{M}$ for 6 days in the dark, and then transferred in the light in WPM GRF 

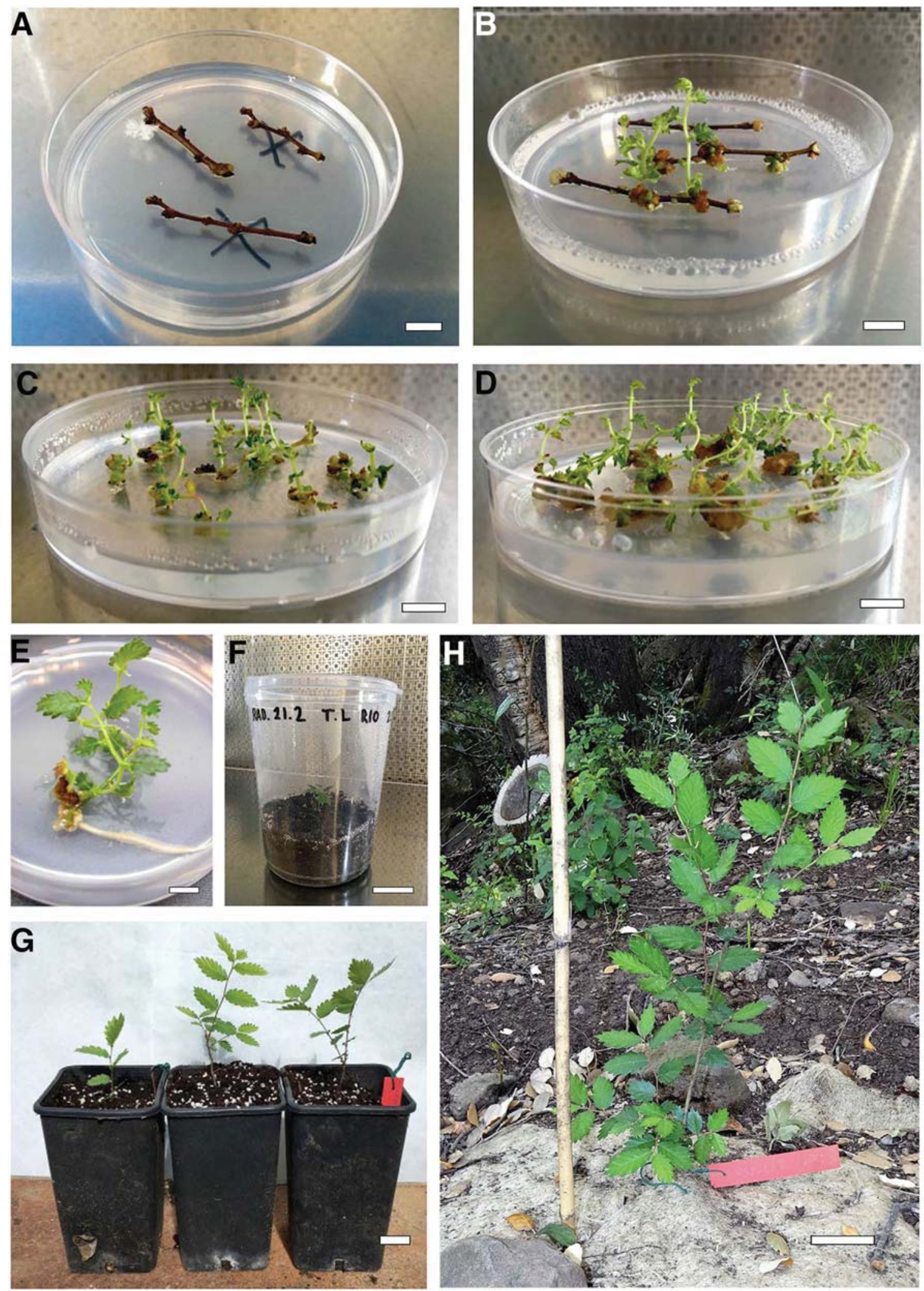

Fig. 1 In vitro procedure for $Z$. sicula plant regeneration from nodal explants. A In vitro introduction of woody explants. B In vitro shoot regeneration. C, D Multiple axillary shoots regeneration, 10 and 20 days after treatment, respectively. E In vitro rooting obtained according to protocol I, 15 days after treatment. F Developed plantlet in a vitro-vent pot. G Acclimatized plantlets in outdoor condition. $\mathbf{H}$ An in vitro regenerated plantlet of $Z$. sicula 15 months after reintroduction in the wild. Bars: A-E $1 \mathrm{~cm} ; \mathbf{F} 5 \mathrm{~cm} ; \mathbf{G} 3 \mathrm{~cm} ; \mathbf{H} 5 \mathrm{~cm}$ 
Table 4 Effect of different growth regulator treatments on axillary bud formation

\begin{tabular}{llll}
\hline Treatment & $\begin{array}{l}\text { No of explants pro- } \\
\text { ducing shoots }(\%)\end{array}$ & $\begin{array}{l}\text { No of shoots } \\
\text { per explant }\end{array}$ & $\begin{array}{l}\text { Mean shoot } \\
\text { length }(\mathrm{cm})\end{array}$ \\
\hline A & $15.0 \pm 3.6^{\mathrm{c}}$ & $1.5 \pm 0.3^{\mathrm{a}}$ & $0.4 \pm 0.1^{\mathrm{c}}$ \\
$\mathrm{B}$ & $13.9 \pm 2.8^{\mathrm{c}}$ & $1.5 \pm 0.3^{\mathrm{a}}$ & $0.5 \pm 0.1^{\mathrm{c}}$ \\
$\mathrm{C}$ & $27.6 \pm 5.4^{\mathrm{b}}$ & $1.5 \pm 0.3^{\mathrm{a}}$ & $1.0 \pm 0.4^{\mathrm{b}}$ \\
$\mathrm{D}$ & $40.0 \pm 4.0^{\mathrm{a}}$ & $2.1 \pm 0.2^{\mathrm{a}}$ & $2.8 \pm 0.2^{\mathrm{a}}$ \\
\hline
\end{tabular}

Each treatment comprises 50 explants. Means \pm SE. Within columns, different letters indicate significant differences (LSD test, $\mathrm{P} \leq 0.05$ )

Table 5 Effect of different preliminary rooting tests based on bi-nodal shoots issued from the multiplication treatment $\mathrm{D}(2.3 \mu \mathrm{M}$ ZEA $)$

\begin{tabular}{lrll}
\hline Treatment & Rooted plants (\%) & No of root per explant & $\begin{array}{l}\text { Mean root } \\
\text { length } \\
(\mathrm{cm})\end{array}$ \\
\hline $\mathrm{E}$ & $37.1 \pm 4.4^{\mathrm{a}}$ & $1.4 \pm 0.03^{\mathrm{a}}$ & $2.6 \pm 0.4^{\mathrm{b}}$ \\
$\mathrm{F}$ & $31.6 \pm 8.8^{\mathrm{a}}$ & $1.5 \pm 0.2^{\mathrm{a}}$ & $3.8 \pm 1.3^{\mathrm{a}}$ \\
$\mathrm{G}$ & $5.0 \pm 2.8^{\mathrm{c}}$ & $1.5 \pm 0.5^{\mathrm{a}}$ & $3.1 \pm 0.1^{\mathrm{b}}$ \\
$\mathrm{H}$ & $8.3 \pm 1.7^{\mathrm{c}}$ & $1.6 \pm 0.3^{\mathrm{a}}$ & $2.5 \pm 0.5^{\mathrm{b}}$ \\
$\mathrm{I}$ & $20.0 \pm 7.6^{\mathrm{b}}$ & $1.0 \pm 0.0^{\mathrm{b}}$ & $4.6 \pm 0.8^{\mathrm{a}}$ \\
$\mathrm{J}$ & $25.0 \pm 5.0^{\mathrm{b}}$ & $1.1 \pm 0.1^{\mathrm{b}}$ & $4.8 \pm 1.3^{\mathrm{a}}$ \\
\hline
\end{tabular}

Each treatment comprises 50 explants. Means \pm SE. Within columns, different letters indicate significant differences (LSD test, $\mathrm{P} \leq 0.05$ )

Table 6 Effect of different rooting treatments on root formation based on treatments $\mathrm{E}$ and $\mathrm{F}$ from the preliminary rooting tests

\begin{tabular}{llll}
\hline Treatment & Rooted plants $(\%)$ & $\begin{array}{l}\text { No of root } \\
\text { per explant }\end{array}$ & Mean root length $(\mathrm{cm})$ \\
\hline E & $42.5 \pm 5.9^{\mathrm{b}, \mathrm{c}}$ & $1.3 \pm 0.1^{\mathrm{b}}$ & $3.6 \pm 0.5^{\mathrm{a}}$ \\
$\mathrm{F}$ & $37.5 \pm 5.9^{\mathrm{c}}$ & $1.3 \pm 0.1^{\mathrm{b}}$ & $2.9 \pm 0.6^{\mathrm{a}}$ \\
E1 & $40.0 \pm 6.5^{\mathrm{b}}$ & $1.6 \pm 0.2^{\mathrm{a}}$ & $2.0 \pm 0.3^{\mathrm{a}, \mathrm{b}}$ \\
$\mathrm{F} 1$ & $50.0 \pm 6.5^{\mathrm{a}, \mathrm{b}}$ & $1.8 \pm 0.2^{\mathrm{a}}$ & $2.4 \pm 0.2^{\mathrm{a}}$ \\
E2 & $65.4 \pm 4.2^{\mathrm{a}}$ & $1.6 \pm 0.2^{\mathrm{a}}$ & $2.7 \pm 0.4^{\mathrm{a}}$ \\
F2 & $42.8 \pm 5.2^{\mathrm{b}, \mathrm{c}}$ & $2.1 \pm 0.3^{\mathrm{a}}$ & $2.0 \pm 0.3^{\mathrm{a}, \mathrm{b}}$ \\
\hline
\end{tabular}

Each treatment comprises 50 explants. Means \pm SE. Within columns, different letters indicate significant differences (LSD test, $\mathrm{P} \leq 0.05$ )

medium (treatment J). Nevertheless, in the whole the microcuttings cultivated under all IBA combinations produced a callus mass at the cut surface, that is usually unsuitable for subsequent root development and plantlets growth. This is the reason why any further attempts involving the use of IBA was discarded and only IAA treatments in various conditions and combinations, as showed in Table 3, were preferred to refine the definitive rooting protocol.

The percentages of rooted plants obtained from the new six IAA-based treatments (Table 6) ranged from 37.5 to $65.4 \%$ (treatments F and E2, respectively). The highest root number per explant (2.1) was instead obtained with

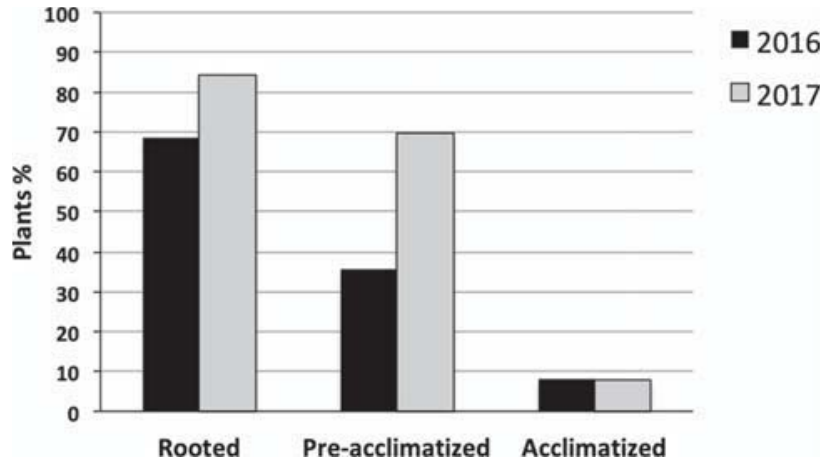

Fig. 2 Efficiency of rooting and acclimatization recorded in trials performed in 2016 and in 2017

treatment F2, but it was not significantly different as compared to most of treatments. With regard to root elongation, the best performance was achieved with treatment E $(3.6 \mathrm{~cm})$, though the value did not differ statistically from the treatments E2 and F. Since in E the percentage of rooted plants $(42.5 \%)$ was not fully satisfactory, we retained as the best performing $(65.4 \%)$ the treatment E2, based on explants cultured for 7 days in WPM medium with $0.1 \%$ PPM and then transferred in WPM supplemented with $5 \mu \mathrm{M}$ IAA and $0.1 \%$ PPM.

All the rooted plantlets obtained from the different rooting trials (Tables 5, 6) were moved as a whole to the preacclimatization (Fig. 1F) and acclimatization (Fig. 1G) phases and, from the total of 600 treated explants, we achieved the following results: rooted $202(33.7 \%)$, preacclimatized $182(30.3 \%)$, acclimatized 26 (4.3\%).

Later, based exclusively on the most effective treatments selected for both shoot multiplication and rooting steps (protocols D and E2, respectively), in 2016 we performed new complete cycles that significantly improved both the rooting and pre-acclimatization rates. From 162 treated explants we obtained $111(68.5 \%)$ rooted plants, out of which $58(35.8 \%)$ survived to pre-acclimatization and $13(8.0 \%)$ successfully acclimatized. In 2017, after having entirely renewed the stock of plant material and concentrated activities in the assumed most suitable season for in vitro rooting (spring), we carried out five additional trials including a total of 139 explants. The success rate further increased in rooting and pre-acclimatization steps (84.2 and $69.8 \%$, respectively) but remained almost unchanged for the final amount of acclimatized plantlets (7.9\%) (Fig. 2).

The total stock of 51 acclimatized plants produced until 2016 were introduced in the wild (Fig. 1H) in two plantation campaigns in 2016 and 2017, respectively. At the end of 2018 only two plants died, with the exceptional survival rate of $96.1 \%$. 


\section{Discussion}

\section{Recalcitrance: a major hurdle}

Designing an effective micropropagation protocol for $Z$. sicula was a very challenging task and involved a great effort that lasted several years. Finally the entire procedure was crowned with success, but the required numerous trials, especially in the shoot multiplication and rooting steps, highlighted the extreme recalcitrance of this species to both propagation and rooting. Hence, the protocol we described represents the very first complete scheme to obtain new plantlets of such a rare plant by tissue cultures.

Recalcitrance is a rather common hurdle in in vitro culture of perennial crops and, within woody plants, taxa characterized by seasonal shoot growth like Z. sicula are usually even more problematic. Most often, recalcitrance is genetically driven (McCown 2000), but as reported for many species (Duhem et al. 1988; Cassells et al. 1988; Onay 2000; Carimi and De Pasquale 2003; Bunn et al. 2011), major difficulties may also arise owed to bacterial or fungal contaminants that hamper the initiation of axenic cultures. Fungal contamination during the in vitro introduction step was relatively difficult to be overcome in Z. sicula. Different species of endophytic fungi, such as Botryosphaeria spp., Neofusicoccum ribis and Diaporthe neotheicola were already known in this plant (Granata et al. 2002; Campo et al. 2018). Despite it is generally recognized a positive interaction between endophytes and host plants (Schulz and Boyle 2005), recent investigations on the Sicilian Zelkova (Campo et al. 2018) reported that the identified fungal species usually live in a latent state in plant tissues, but under stress conditions (e.g. drought stress) they can become responsible of several diseases by inducing bark canker on branches and stems. According to that, in vitro techniques can have the additional value to yield plants with a lower or null presence of potential parasitic endophytes, allowing a higher success of reintroduction efforts in the wild.

As a matter of fact, temperate plants show a clear seasonal pattern in their response to tissue culture; as a consequence, the explants have to be collected in the most suitable time of the year (Benson 2000; Kartsonas and Papafotiou 2007). Commonly, to avoid loss of material due to culture contamination, the use of young and actively growing spring shoots is preferred (Carra et al. 2012). In contrast to that, however, in our case it was very difficult to introduce in vitro plant material harvested in spring and summer due to lethal browning of shoots and high contamination rates, while plant material collected in winter reacted more positively, with a high percentage of successful establishment. This result is consistent with those described for other woody taxa such as Acacia sinuata (Vengadesan et al. 2003) and Fagus sylvatica, for which tissue culture could be started only with dormant buds harvested in February and March (Nadel et al. 1991; Vieitez et al. 2003).

As already found for the congener species Zelkova sinica (Gao et al. 1996) and Z. schneideriana (Jin et al. 2009), WPM confirmed as an effective medium for callus induction. However, as a whole, a crucial factor in micropropagation is the type and the concentration of cytokinin applied in the multiplication phase. BAP and ZEA are the most widely used cytokinins, with satisfactory results for shoot proliferation in woody trees (Haddad et al. 2018; Grigoriadou et al. 2002; Martinez et al. 2017). BAP was effective in shoot regeneration of $Z$. schneideriana (Jin et al. 2009), while for Z. sicula the best results in terms of shoot proliferation were provided by ZEA, consistently to data obtained for other woody plants like Olea europaea (Lambardi and Rugini 2003), Arbutus unedo (Papagianni et al. 2017), Arbutus andrachne (Bertsouklis and Papafotiou 2009) and Cinnamomum camphora (Babu et al. 2003). ZEA is also known to have additional positive and useful effects on micropropagation processes. In fact, it has been reported to enhance shoot elongation (Debnath 2005), which in turn is a promoting feature for the following rooting step (Tao and Sugiura 1992), and to induce low callus formation at the base of explants (Marks and Simpson 1994). This last one is a desirable trait ensuring the genetic stability of regenerated plantlets especially devoted to germplasm conservation and reinforcement of natural populations (Giri et al. 2004). Our data confirm these findings, since the shoots obtained under this culture conditions were the longest ones among the different treatments.

Successful root initiation is a key step in clonal propagation of woody trees for which rooting rates are usually low, especially when adult material is used. Without an effective and well-structured root system, plant acclimatization is prone to failure and the success of the entire process will be poor. According to our previous experiences, as well as to definitions from literature, Z. sicula could be defined as "recalcitrant to root" (Benson 2000), so root induction required the adoption of different strategies and manipulations. Initially, rooting of $Z$. sicula was attempted using as auxins IBA and IAA. Rooting was obtained with both auxins but with significant differences. The best results, globally achieved with IAA whatever the concentration, actually contrasted with those reported for other taxa, e.g. Z. schneideriana (Jin et al. 2009), Liquidambar orientalis (Bayraktar et al. 2015), Quercus ilex (Martinez et al. 2017) and Olea europaea subsp. laperrinei (Haddad et al. 2018), whose adventitious root formation was more effectively induced by IBA. Therefore, the promising results obtained with IAA prompted a deeper investigation on its effectiveness, 
involving changes in standard cultural conditions and time of exposure to auxin.

As described above, already in the shoot propagation step the use of ZEA not only induced higher amounts of new shoots production, but also favoured internode elongation, which is essential to obtain a good rooting percentage, especially in woody plants (Kevers et al. 2009). Also changes in medium composition during the first phase of the process revealed fruitful. After the propagation phase, shoots were transferred in a medium deprived of growth regulators for 7 days, before rhizogenic treatment. This approach was preferred for two different reasons: (i) rooting aptitude is favoured by a preliminary accumulation of endogenous IAA, a situation that could be obtained only when the levels of cytokinins absorbed from the multiplication medium decrease (Bouza et al. 1994) and (ii) the 7-day period in PGRs free medium is probably needed to decrease the peroxidase concentrations which is induced by wounding and is responsible for IAA oxidation and consequent inactivation (De Klerk et al. 1999). Moreover, before root induction, cells must become competent and, during this phase, an auxin treatment is not necessarily required (Kevers et al. 2009). Thanks to such adjustments, the success rate in terms of rooted plants of more than $84 \%$ is to be considered quite exceptional as referred to a species initially classified as "recalcitrant to rooting".

\section{Acclimatization: the last challenge}

The broad success in any process of plant propagation is strictly dependent on the quantity of newly produced plants able to survive in field conditions after acclimatization ( $\mathrm{Ziv}$ 1986). Contrarily to the excellent results obtained for the congener Z. schneideriana (Jin et al. 2009), the total number of acclimatized plants of $Z$. sicula is actually rather modest as compared to the amount of rooted plants. The low success of the acclimatization stage could be due to several factors, resulting in the interruption of growth and a progressive decline and death: (i) the unsuitable soil substrate to which plants were transferred; (ii) the in vitro regenerated roots could be incompletely functional owed to low connection with the conduction systems; (iii) a weak structure of the root system, yet inappropriate for transplanting (Amoo et al. 2011), (iv) water stress, due to deficient root system, and photoinhibition that may promote production of noxious reactive oxygen species (Bunn et al. 2011).

Whatever the reason of such yet unsatisfactory results, nonetheless the first 51 micropropagated plantlets of this very challenging species have been reintroduced in the wild within the framework of activities foreseen by the conservation project Zelkov@azione (http://www.zelkovazio ne.eu/). Plantations, carried out according to the principles of "Assisted Colonization" (Booker et al. 2011), were fully successful (Fig. 1H), with an exceptionally high survival rate. These promising results can also represent a starting point to test the effectiveness of this protocol for near relatives with similar conservation problems, such as Z. abelicea from Crete, whose most populations suffer for insufficient or null sexual regeneration (Kozlowski et al. 2014).

However, additional experiments need to be done in order to overcome the failures in the acclimatization phase and improve the efficiency of the entire process. New trials could address some changes in cultural conditions during the multiplication step such as the use of meta-topolin, a cytokinin that was recently found to have a positive interference with rooting (Aremu et al. 2012), hence assumed to promote plant acclimatization. Also, understanding through anatomical studies if the adventitious roots formed in vitro are functional and effectively connected with the microcutting conduction tissues is decisive in order to optimize acclimatization.

\section{Conclusions}

In this work, an effective in vitro propagation protocol was developed for the first time from axillary buds collected from mature plants of $Z$. sicula, a threatened relict tree at the brink of extinction. Despite some refinements are still needed, the accomplishment of the entire reproduction process allowed to overcome the problems of seed sterility of this rare species that were a major obstacle to regenerate new plantlets for programs of reintroduction or ex situ conservation. After the initial difficulties with sterilization, which in turn caused numerous failures in the multiplication and rooting stages, the global result may be deemed rather satisfactory and the recalcitrance may be considered partially overcome.

Concerning the problems associated to the acclimatization step, for sure they do not depend on a single factor. Accordingly, in the next foreseen experiments some additional aspects specifically addressed to the acclimatization will be investigated, but in order to finally fulfil our expectations also the previous steps will be taken into account at some extent. In any case, the achievements obtained so far already allowed the creation of four new small viable populations and the diffusion of a few trees in plant repositories, hence significantly contributing to reduce the risk of extinction of this very peculiar relict species.

Acknowledgements The results of this work are part of the activities funded by the Programme LIFE+, Project LIFE10 NAT/IT/000237 Zelkov@zione (http://www.zelkovazione.eu/). The authors are also grateful to the Fondation Franklinia for its valuable support.

Author contributions AC, GG, LF and GK conceived the paper. LA, $\mathrm{AC}, \mathrm{CC}, \mathrm{OB}, \mathrm{FLB}$ and $\mathrm{AM}$ designed and performed the in vitro experiments. AC, FC and GG supervised all the experiments. AC, CC, FC, 
SP and GG wrote the manuscript. All authors contributed to the discussions and approved the final manuscript.

\section{Compliance with ethical standards}

Conflict of interest The authors declare that they have no conflict of interest.

\section{References}

Alkemade R, van Oorschot M, Miles L, Nellemann C, Bakkenes M, ten Brink B (2009) GLOBIO3: a framework to investigate options for reducing global terrestrial biodiversity loss. Ecosystems 12:374390. https://doi.org/10.1007/s10021-009-9229-5

Amoo SO, Finnie JF, Van Staden J (2011) The role of meta-topolins in alleviating micropropagation problems. Plant Growth Regul 63:197-206. https://doi.org/10.1007/s10725-010-9504-7

Aremu AO, Bairu MW, Doležal K, Finnie JF, Van Staden J (2012) Topolins: a panacea to plant tissue culture challenges? Plant Cell Tiss Org 108:1-16. https://doi.org/10.1007/s11240-011-0007-7

Babu KN, Sajina A, Minoo D, John CZ, Mini PM, Tushar KV, Rema J, Ravindran PN (2003) Micropropagation of camphor tree (Cinnamomum camphora). Plant Cell Tiss Org 74:179-183. https:// doi.org/10.1023/A:1023988110064

Bayraktar M, Hayta S, Parlak S, Gurel A (2015) Micropropagation of centennial tertiary relict trees of Liquidambar orientalis Miller through meristematic nodules produced by cultures of primordial shoots. Trees-Struct Funct 29:999-1009. https://doi.org/10.1007/ s00468-015-1179-2

Benson EE (2000) Special symposium: In vitro plant recalcitrance: an introduction. In vitro Cell Dev Biol 36: 141-148. https://doi. org/10.1007/s11627-000-0029-Z

Bertsouklis KF, Papafotiou M (2009) In vitro propagation of Arbutus andrachne L. Acta Hort 813:477-480. https://doi.org/10.17660/ ActaHortic.2009.813.63

Bouza L, Jacques M, Sotta B, Miginiac E (1994) Relations between auxin and cytokinin contents and in vitro rooting of tree Peony (Paeonia suffruticosa Andr.). Plant Growth Regul 15:69-73. https ://doi.org/10.1007/BF00024678

Brooker R, Britton A, Gimona A, Lennon J, Littlewood N (2011) Literature review: species translocations as a tool for biodiversity conservation during climate change. Scott Nat Heritage Comm Rep 440:68 p. https://doi.org/10.1111/j.1523-1739.2009.01264.x

Bunn E, Turner SR, Dixon KW (2011) Biotechnology for saving rare and threatened flora in a biodiversity hotspot. In vitro Cell Dev Biol 47:188-200. https://doi.org/10.1007/s11627-011-9340-0

Campo G, Mazzeo G, Nucifora S, Perrotta G, Sidoti A, Bella S (2018) Insects and fungi on the relict Zelkova sicula (Rosales, Ulmaceae) in Sicily (Italy): new records and known species in a short review. Redia 101:23-30. https://doi.org/10.19263/REDIA-101.18.04

Carimi F, De Pasquale F (2003) Micropropagation of Citrus. In: Jain SM, Ishii K (eds) Micropropagation of woody trees and fruits. Kluwer, Dordrecht, pp 589-619. https://doi. org/10.1007/978-94-010-0125-0_20

Carra A, Del Signore MB, Sottile F, Ricci A, Carimi F (2012) Potential use of new diphenylurea derivatives in micropropagation of Capparis spinosa L. Plant Growth Regul 66:229-237. https://doi. org/10.1007/s10725-011-9645-3

Cassells AC, Carney BF, McCarthy E, McHugh A, Harmey MA (1988) Problems posed by cultivable bacterial endophytes in the establishment of axenic cultures of Pelargonium $\mathrm{x}$ domesticum: the use of Xanthomonas pelargonii-specific ELISA, DNA probes and culture indexing in the screening of antibiotic treated and untreated donor plants. Acta Hortic 225:153-162. https:// doi.org/10.17660/ActaHortic. 1988.225.16

Christe C, Kozlowski G, Frey D, Bétrisey S, Maharramova E, Garfì G, Pirintsos S, Naciri Y (2014) Footprints of past intensive diversification and structuring in the genus Zelkova (Ulmaceae) in South-western Eurasia. J Biogeogr 41:1081-1093. https://doi. org/10.1111/jbi.12276

De Klerk GJ, Van Der Krieken WM, de Jong JC (1999) The formation of adventitious roots: new concepts, new possibilities. In vitro Cell Dev Biol 35:189-199

Debnath SC (2005) Micropropagation of lingonberry: influence of genotype, explant orientation, and overcoming TDZ-induced inhibition of shoot elongation using zeatin. HortScience 40:185-188

Duhem K, Le Mercier N, Boxus PH (1988) Difficulties in the establishment of axenic in vitro cultures of field collected coffee and cacao germplasm. Acta Hortic 225:67-76. https://doi.org/10.17660/ ActaHortic. 1988.225.7

Gao YY, Wang YN, Jiang JH (1996) Tissue culture of Zelkova serrata. Q J Chin For 29:171-186

Garfì G (1997) Première contribution à l'étude de Zelkova sicula (Ulmaceae). In: une relique de la flore tertiaire, endémique de la Sicile sud-orientale (Systématique - Caryologie - Dynamique de la croissance - Dendroécologie). + annexes, Marseille, 235 Thèse Doct, Univ. D'

Garfì G, Buord S (2012) Relict species and the challenges for conservation: the emblematic case of Zelkova sicula Di Pasquale, Garfi et Quézel and the efforts to save it from extinction. Biodivers J 3:281-296

Garfì G, Carimi F, Pasta S, Rühl J, Trigila S (2011) Additional insights on the ecology of the relic tree Zelkova sicula Di Pasquale, Garfi et Quézel (Ulmaceae) after the finding of a new population. Flora 206:407-417. https://doi.org/10.1016/j.flora.2010.11.004

Garfì G, Pasta S, Fazan L, Kozlowski G (2017) Zelkova sicula. The IUCN Red List of Threatened Species 2017: e.T61678A86134112. http://dx.doi.org/10.2305/IUCN.UK.2017-3.RLTS. T61678A86134112.en. Accessed 19 Mar 2018

Giri CC, Shyamkumar B, Anjaneyulu C (2004) Progress in tissue culture, genetic transformation and applications of biotechnology to trees: an overview. Trees Struct Funct 18:115-135. https://doi. org/10.1007/s00468-003-0287-6

Granata G, Sidoti A, Tamburino V (2002) Funghi endofiti in arbusti di Zelkova sicula. In: Atti del Convegno nazionale "L'endofitismo di funghi e batteri patogeni in piante arboree ed arbustive". SassariTempio Pausania, 19-21 maggio 2002, pp. 303-311

Gratzfeld J, Kozlowski G, Fazan L, Buord S, Garfî G, Pasta S, Gotsiou P, Fournaraki C, Dimitriou D (2015) Whither rare relict trees in a climate of rapid change? Conservation challenges of Zelkova sicula and Z. abelicea: two Mediterranean narrow endemics. BGjournal 12:21-25

Grigoriadou K, Vasilakakis M, Eleftheriou EP (2002) In vitro propagation of the Greek olive cultivar 'Chondrolia Chalkidikis'. Plant Cell Tiss Org Cult 71:47-54. https://doi.org/10.1023/A:10165 78614454

Haddad B, Carra A, Saadi A, Haddad N, Mercati F, Gristina AS, Boukhalfa S, Djillali A, Carimi F (2018) In vitro propagation of the relict Laperinne's olive (Olea europaea L. subsp. laperrinei). Plant Biosyst 152:621-630. https://doi.org/10.1080/11263 504.2017.1306002

Hummer KE (1999) Biotechnology in plant germplasm acquisition. In: Benson D (Ed.), Benson E Plant conservation biotechnology. CRC, London, pp 25-39

Jin XL, Zhang RQ, Zhang DL, He P, Cao FX (2009) In vitro plant regeneration of Zelkova schneideriana, an endangered woody species in China, from leaf explants. J Hort Sci Biotechnol 84:415420. https://doi.org/10.1080/14620316.2009.11512542 
Kartsonas E, Papafotiou M (2007) Mother plant age and seasonal influence on in vitro propagation of Quercus euboica Pap., an endemic, rare and endangered oak species of Greece. Plant Cell Tiss Org Cult 90:111-116. https://doi.org/10.1007/s11240-007-9232-5

Keskitalo MK (1999) Exploring biodiversity to enhance bioactivity in the genus Tanacetum through protoplast fusion. Academic Dissertation, University of Finland, Department of Plant Production, Section of Crop Husbandry, Publication No. 53, p 113

Kevers C, Hausman JF, Faivre-Rampant O, Dommes J, Gaspar T (2009) What we have learned about the physiology of in vitro adventitious rooting of woody plants and how it relates to improvements in the practice. In: Niemi K (ed) Adventitious root formation of forest trees and horticultural plants: from genes to applications. Research Signpost, Kerala, pp 400-417

Kozlowski G, Frey D, Fazan L, Egli B, Bétrisey S, Gratzfeld J, Garfì G, Pirintsos S (2014) The Tertiary relict tree Zelkova abelicea (Ulmaceae): distribution, population structure and conservation status on Crete. Oryx 48:80-87. https://doi.org/10.1017/S0030 605312001275

Krishnan PN, Decruse SW, Radha RK (2011) Conservation of medicinal plants of Western Ghats, India and its sustainable utilization through in vitro technology. In vitro Cell Dev Biol 47: 110-122. https://doi.org/10.1007/s11627-011-9344-9

Lambardi M, Rugini E (2003) Micropropagation of olive (Olea europaea L.). In: Jain SM, Ishii K (eds) Micropropagation of woody trees and fruits. Kluwer Academic Publishers, The Netherlands, pp 621-646. https://doi.org/10.1007/978-94-010-0125-0

Lloyd G, McCown B (1980) Commercially-feasible micropropagation of mountain laurel, Kalmia latifolia, by use of shoot-tip culture. Comb Proc Int Plant Propag Soc 30: 421-427

Mallón R, Rodríguez-Oubiña J, González ML (2010) In vitro propagation of the endangered plant Centaurea ultreiae: assessment of genetic stability by cytological studies, flow cytometry and RAPD analysis. Plant Cell Tiss Org Cult 101:31-39. https://doi. org/10.1007/s11240-009-9659-y

Marks TR, Simpson SE (1994) Factors affecting shoot development in apically dominant Acer cultivars in vitro. J Hort Sci 69:543-551. https://doi.org/10.1080/14620316.1994.11516486

Martínez MT, Corredoira E, Vieitez AM, Cernadas MJ, Montenegro R, Ballester A, Vieitez FJ, San José MC (2017) Micropropagation of mature Quercus ilex L. trees by axillary budding. Plant Cell Tiss Org Cult 131:499-512. https://doi.org/10.1007/s1124 $0-017-1300-x$

McCown BH (2000) Special symposium: In vitro plant recalcitrance. Recalcitrance of woody and herbaceous perennial plants: Dealing with genetic predeterminism. In vitro Cell Dev Biol 36: 149-154. https://doi.org/10.1007/s11627-000-0030-6

Nadel BL, Altman A, Pleban S, Hüttermann A (1991) In vitro development of mature Fagus sylvatica L. buds. I. The effect of medium and plant growth regulators on bud growth and protein profiles. J Plant Physiol 138:596-601. https://doi.org/10.1016/S0176 $-1617(11) 80248-8$

Onay A (2000) Micropropagation of pistachio from mature trees. Plant Cell Tiss Org Cult 60:159-163. https://doi.org/10.1023/A:10064 23914951

Papagianni A, Papafotiou M, Bertsouklis KF (2017) In vitro propagation of Arbutus unedo var. rubra starting from seedlings and adult parental plants. Acta Hort 1189:469-472. https://doi.org/10.17660 /ActaHortic.2017.1189.93

Reed BM, Sarasan V, Kane M, Bunn E, Pence VC (2011) Biodiversity conservation and conservation biotechnology tools. In vitro Cell Dev Biol 47: 1-4. https://doi.org/10.1007/s11627-010-9337-0

San José MC, Martínez MT, Cernadas MJ, Montenegro R, Mosteiro F, Corredoira E (2017) Biotechnological efforts for the propagation of Quercus lusitanica Lam., an endangered species. Trees Struct Funct 31:1571-1581. https://doi.org/10.1007/s00468-017-1570-2

Sarasan V, Cripps R, Ramsay MM, Atherton C, McMichen M, Prendergast G, Rowntree JK (2006) Conservation in vitro of threatened plants: progress in the past decade. In vitro Cell Dev Biol 42:206-214. https://doi.org/10.1079/IVP2006769

Schulz B, Boyle C (2005) The endophytic continuum. Mycol Res 109:661-686. https://doi.org/10.1017/S095375620500273X

Tao R, Sugiura A (1992) Micropropagation of Japanese persimmon (Diospyros kaki L.). High-tech and micropropagation II. In: Bajaj YPS (ed) Biotechnology in Agriculture and Forestry, vol 18. Springer, Berlin, pp 424-440. https://doi.org/10.1007/978-3642-76422-6_22

Vengadesan G, Ganapathi A, Anand RP, Selvaraj N (2003) In vitro propagation of Acacia sinuata (Lour.) Merr. from nodal segments of a 10-year-old tree. In vitro Cell Dev Biol 39:409-414. https:// doi.org/10.1079/IVP2003421

Vieitez AM, San-Jose MC, Sánchez MC, Ballester A (2003) Micropropagation of Fagus spp. In: Jain SM, Ishii K (eds) Micropropagation of Woody Trees and Fruits. Kluwer Academic Publishers, Dordrecht, pp 181-215. https://doi. org/10.1007/978-94-010-0125-0

Ziv M (1986) In vitro hardening and acclimatization of tissue culture plants. In: Withers LA, Alderson PG (eds) Plant tissue culture and its agricultural application. Butterworth, London, pp 187-196 